\title{
Ada Nilai Islami dalam Pembelajaran Matematika
}

\author{
HANA DWI WAHYUNI \\ Jurusan Tadris Matematika, Institut Agama Islam Negeri (IAIN) Tulungagung \\ Jl. Mayor Sujadi Timur No. 46 Tulungagung \\ e-mail: hanadw889@gmail.com
}

\begin{abstract}
ABSTRAK
Ibadah dan akhlak yang harus diimplementasikan dalam kehidupan sehari-hari dalam berbagai aspek kehidupan manusia, baik dalam berhubungan dengan Tuhan, dengan sesama manusia, maupun dengan alam sekitarnya. Jika nilai-nilai ini bisa direalisasikan dalam kehidupan manusia, maka akan dihasilkan manusia yang paripurna (insan kamil) dan terciptalah kehidupan yang bermartabat. Salah satu sarana mengimplemrntasikan nilai islami adalah melalui pembelajaran matematika. Matematika memiliki pengaruh yang besar dalam kehidupan manusia. Agar matematika dapat dirasakan siswa sebagai bagian dari hidup, setiap materi matematika yang akan diajarkan harus dapat ditunjukkan aspek-aspek tertentu yang mengandung nilai-nilai dalam kehidupan. Guna menanamkan nilai-nilai Islam melalui proses pembelajaran matematika, diperlukan strategi yang tepat. Beberapa strategi pembelajaran yang dikaitkan dengan penanaman nilai-nilai ajaran islam yang dapat dilakukan dalam pembelajaran mata pelajaran matematika, adalah selalu menyebut nama Allah, menggunakan istilah dan nama-nama islami, Ilustrasi visual, penelusuran sejarah, menyajikan materi matematika yang bermuatan nilai Islami.
\end{abstract}

Kata Kunci: nilai islami, pembelajaran matematika.

\section{PENDAHULUAN}

Tujuan pendidikan dijelaskan dalam undang-undang No. 20 tahun 2003 pasal 3 menyatakan bahwa pendidikan nasional berfungsi mengembangkan kemampuan dan membentuk watak serta peradaban bangsa yang bermartabat dalam rangka mencerdaskan bangsa, bertujuan mengembangkan potensi peserta didik menjadi manusia yang beriman dan bertakwa kepada Tuhan Yang Maha Esa, berakhlak mulia, sehat berilmu, cakap, kreatif, mandiri, dan menjadi warga negara yang demokratis serta bertanggung jawab. ${ }^{1}$ Hal ini menunjukkan bahwa pendidikan diselaraskan dengan perkembangan teknologi, selain itu pendidikan juga diharapkan mampu membangun nilai dan watak peserta didik yang berkualitas melalui nilai-nilai agama.

Nilai-nilai agama Islam dapat dipelajari melalui pembelajaran matematika. Dijelaskan La jamaa dalam Beni Asyhar dan Muniri, matematika sebagai salah satu disiplin ilmu pengetahuan dapat digunakan sebagai pendekatan dalam menjelaskan beberapa doktrin dalam ajaran Islam. Penggunaan

\footnotetext{
${ }^{1}$ Tim Redaksi FOKUSMEDIA, "HIMPUNAN PERUNDANG-UNDANGAN TENTANG SISTEM PENDIDIKAN NASIONAL" (Bandung: FOKUSMEDIA, 2006), 38.
} 
pendekatan matematika di sini bukan berarti bahwa lemahnya doktrin ajaran Islam tersebut melainkan hanya untuk menambah keyakinan umat Islam bahwa semua ilmu pengetahuan itu bernilai kebaikan dan dapat mengantarkan kepada kebaikan yang hakiki serta meningkatkan keimanan dan kedekatan kepada Allah SWT. ${ }^{2}$

Matematika memiliki pengaruh yang besar dalam kehidupan manusia. Disadari maupun tidak, sebenarnya seseorang tidak lepas dengan matematika. Tetapi bagi sebagian besar orang menganggap bahwa matematika merupakan mata pelajaran yang amat berat dan sulit. Salah satu penyebabnya karena kajian matematika yang bersifat abstrak. Kemampuan matematika seseorang sangat dipengaruhi penguasaan matematikanya sejak dini. ${ }^{3}$ Oleh karena itu, matematika perlu diperkenalkan dan diajarkan kepada siswa semenarik mungkin. Apabila matematika telah menjadi hal yang menarik untuk dipelajari, maka siswa akan merasakan bahwa matematika memang merupakan bagian dari hidup karena keurgenan matematika tersebut. Agar matematika dapat dirasakan siswa sebagai bagian dari hidup, setiap materi matematika yang akan diajarkan harus dapat ditunjukkan aspek-aspek tertentu yang mengandung nilai-nilai dalam kehidupan. Salah satu nilai dalam kehidupan yaitu nilai islami berupa nilai akidah, nilai syari'ah dan nilai akhlak.

\section{PEMBAHASAN}

\section{Pembelajaran Matematika yang Memuat Nilai Islami}

Secara umumnya pembelajaran matematika dilakukan secara parsial, yaitu mata pelajaran terpisah dengan mata pelajaran lain. Pembelajaran matematika secara parsial, tidak menanamkan nilai-nilai agama dalam muatan-muatan pelajarannya. Fokus pembelajaran parsial hanya pada ketercapaian tujuan materi pelajaran yang cenderung hanya menyentuh aspek kognitif. Akibatnya, pelajaran matematika kering dari pesan-pesan moral dan upaya pembentukan pribadi yang utuh. Pembelajaran matematika yang memuat nilai-nilai Islam, disamping bertujuan tercapainya pemahaman dan kemampuan matematika siswa, juga dimaksudkan untuk menanamkan nilai-nilai Islam pada siswa. ${ }^{4}$

Nilai islami dalam pembelajaran matematika yang dimaksud disini adalah pembelajaran yang dilakukan dengan memberikan nilai-nilai keislaman dalam setiap pembelajarannya baik dalam pembukaan pembelajaran, materi, maupun pada contoh soal. Dalam hal ini nilai islami yang diintegrasikan ke dalam pembelajaran matematika meliputi: (a) nilai akidah, (b) nilai syari'ah, (c) nilai akhlak.

Menurut Lukman Hakim yang dikutip nihayati, aspek nilai-nilai ajaran Islam pada intinya dapat dibedakan menjadi tiga jenis, yaitu nilai-nilai akidah, nilai-nilai syari'ah dan nilai-nilai akhlak.

\footnotetext{
${ }^{2}$ Beni Asyhar and Muniri, "Matematika Sebagai Alternatif Media Dakwah," in Prosiding SI MaNIs (Seminar Nasional Integrasi Matematika Dan Nilai-Nilai Islami), vol. 1, 2017, 335-41.

${ }^{3}$ Annisah Kurniati, "Mengenalkan Matematika Terintegrasi Islam Kepada Anak Sejak Dini," Suska Journal of Mathemathics Education 1, no. 1 (2015): 1-8.

${ }^{4}$ Salafudin, "YANG BERMUATAN NILAI ISLAM," JURNAL PENELITIAN 12, no. 2 (2015): 223-43.
} 
Nilai-nilai akidah mengajarkan manusia untuk percaya akan adanya Allah Yang Maha Esa dan Maha Kuasa sebagai Sang Pencipta alam semesta, yang akan senantiasa mengawasi dan memperhitungkan segala perbuatan manusia di dunia. Dengan merasa sepenuh hati bahwa Allah itu ada dan Maha Kuasa, maka manusia akan lebih taat untuk menjalankan segala sesuatu yang telah diperintahkan oleh Allah dan takut untuk berbuat dhalim atau kerusakan di muka bumi ini. Keyakinan hal tersebut akan mejadikan manusia selalu berbuat ihsan (baik), kemudian melahirkan sifat muhsin (merasa diawasi oleh Allah). Nilai-nilai syari'ah mengajarkan pada manusia agar dalam setiap perbuatannya senantiasa dilandasi hati yang ikhlas guna mencapai ridho Allah. Pengamalan konsep nilai-nilai syari'ah akan melahirkan manusia-manusia yang adil, disiplin, jujur, bertanggung jawab, dan suka membantu sesamanya. Sedangkan nilai-nilai akhlak mengajarkan kepada manusia untuk bersikap dan berperilaku yang baik sesuai norma atau adab yang benar dan baik, sehingga akan membawa pada kehidupan manusia yang tenteram, damai, harmonis, dan seimbang. Dengan demikian jelas bahwa nilai-nilai ajaran Islam merupakan nilai-nilai yang akan mampu membawa manusia pada kebahagiaan, kesejahteraan, dan keselamatan manusia baik dalam kehidupan di dunia maupun kehidupan di akhirat kelak. ${ }^{5}$

Ibadah dan akhlak yang harus diimplementasikan dalam kehidupan sehari-hari dalam berbagai aspek kehidupan manusia, baik dalam berhubungan dengan Tuhan, dengan sesama manusia, maupun dengan alam sekitarnya. Jika nilai-nilai ini bisa direalisasikan dalam kehidupan manusia, maka akan dihasilkan manusia yang paripurna (insan kamil) dan terciptalah kehidupan yang bermartabat.

Guna menanamkan nilai-nilai Islam melalui proses pembelajaran matematika, diperlukan strategi yang tepat. Beberapa strategi pembelajaran yang dikaitkan dengan penanaman nilai-nilai ajaran islam yang dapat dilakukan dalam pembelajaran mata pelajaran matematika, adalah selalu menyebut nama Allah, menggunakan istilah dan nama-nama islami, Ilustrasi visual, penelusuran sejarah, menyajikan materi matematika yang bermuatan nilai Islami.

Berikut secara rinci penjelasan strategi pembelajaran yang menanaman nilai-nilai ajaran islam, antara lain:

1. Menyebut nama Allah saat memulai dan mengakhiri belajar .

Sebelum memulai belajar segala sesuatu termasuk matematika, ditradisikan diawali dengan membaca Basmalllah dan berdoa bersama-sama. Kemudian diakhiri dengan bacaan alhamdulillah.

2. Menggunakan istilah dan nama-nama islami

Istilah dalam matematika sangat banyak ragamnya. Diantara istilah tersebut dapat dinuansai dengan peristilahan dalam ajaran islam, antara lain : penggunaan nama, peristiwa atau

\footnotetext{
${ }^{5}$ Nihayati, "Integrasi Nilai-Nilai Islam Dengan Materi Himpunan (Kajian Terhadap Ayat-Ayat AlQur'an)" 3, no. 1 (2017): 65-77.
} 
benda yang bernuansa Islam. Misalnya : nama (Ahmad, Fatimah, Khodidjah, Aisyah, Aminah), peristiwa (mewakafkan tanah dengan ukuran luas tertentu, kecepatan perjalanan ketika melakukan sa'i dari Saffa ke Marwa waktu ibadah haji), benda-benda ( himpunan kitab-kitab suci, himpunan masjid). ${ }^{6}$

3. Ilustrasi visual

Media dan alat-alat peraga yang digunakan dalam pembelajaran pada mata pelajaran matematika dapat divisualisasikan dengan gambar-gambar atau potret yang islami. Misalnya dalam membicarakan simetri dapat dicontohkan ornamen-ornamen-ornamen masjid atau mushollah, dalam pembahasan bangun ruang dapat menampilkan ka'bah, dalam pembahasan bangun datar dapat menampilkan luas sajaddah. ${ }^{7}$

4. Penelusuran sejarah

Penjelasan suatu kompetensi dalam pelajaran matematika dapat dikaitkan dengan sejarah perkembangan ilmu pengetahuan oleh ilmuwan muslim. Misalnya dalam pembelajaran menjelaskan tentang Sayyidina Ali yang mengenalkan Istilah KPK (Kelipatan Persekutuan Terkecil), Al-Khawarizmi yang memperkenalkan desimal atau persepuluhan, penggunaan variabel dan simbol-simbol, penemuan simbol pi, menyusun daftar logaritma, metode aljabar, rumus $\mathrm{ABC}$, dan $\mathrm{Abu} \mathrm{Al}$ Wafa yang memperkenalkan konsep tangen, cotangen, secan, cosecan dalam trigonometri. Dan masih banyak lagi ilmuwan muslim lainnya. ${ }^{8}$

5. Menyajikan materi matematika yang bermuatan nilai Islami

Berikut merupakan contoh materi pelajaran matematika yang bermuatan nilai-nilai islami:

a. Konsep barisan bilangan pecahan

Sebagai contoh, coba kita perhatikan manakah yang lebih besar antara 1/2 dengan $1 / 3$ ? yang pastinya $1 / 2$ yang lebih besar. Coba perhatikan lagi! 1/3 dengan $1 / 4$ yang lebih besar? 1/4 dengan 1/5 , 1/5 dengan 1/6 dan seterusnya. Yang pastinya bilangan sebelah kiri akan lebih besar sehingga, semakin besar nilai dari sebuah penyebut (denominator) maka bilangan itu akan semakin kecil (bilangan pecahan) sehingga akhirnya semakin besar pembagi (dalam artian tak hingga) maka $1 /$ tak hingga $=0$. Konsep itu memiliki makna jika 1 = Alloh (Al-ahad) yang diposisikan sebagai bilangan yang dibagikan (bahwa Allah itu pemberi rahmat dan hidayah), dan tak hingga= manusia sebagai abdi Allah. Tak hingga menandakan sifat manusia yang berlaku sombong, angkuh dan merasa dirinya paling besar dengan segala kekuasaan dan kepintarannya. Jika manusia berlaku hal demikian maka dimata Allah harganya “ 0 ” ( $(1 /$ tak hinnga $=0)$.

\footnotetext{
${ }^{6}$ Salafudin, "YANG BERMUATAN NILAI ISLAM."

7 Ibid.

${ }^{8}$ Rizqon Halal Syah Aji, "KHAZANAH SAINS DAN MATEMATIKA DALAM ISLAM," no. 95 (2014). 
Sekarang, coba perhatikan: 1/(1/2) dengan 1/(1/3) lebih besar mana? yang pastinya bilangan sebelah kanan akan lebih besar sehingga, semakin kecil nilai pembagi maka nilai sebuah pecahan akan menjadi lebih besar sehingga akhirnya: $1 / 0=$ tak terdefinisi, apa artinya? kembali lagi dari konsep sebelumnya.

Nilai yang terkandung pada kondisi tersebut jika seseorang merasa tak punya daya dan upaya di hadapan Allah, selalu berserah diri pada Allah yang dalam hal ini dilambangkan dengan "0"maka insya Allah akan bernilai tak ternilai di hadapan Allah. dalam hal ini yang ingin saya tekankan adalah betapapun berkuasanya kiat, sepandai apapun kita dan sekaya apapun kita itu semua tidak lepas dari kekuasaan Allah ( la haula walaquwwata illa billahil 'aliyyil 'adzimmm). Marilah kita bersama-sama berlomba untuk MENGENOLKAN diri dihadapan Allah dan selalu bertawakal kepada Allah. ${ }^{9}$ Hal tersebut sesuai dengan firman Allah.

...Kemudian apabila kamu telah membulatkan tekad, maka bertawakallah kepada Allah. Sesungguhnya Allah menyukai orang-orang yang bertawakkal kepada-Nya. (QS. Ali Imron: 155)

b. Konsep perkalian

Telah kita ketahui bahwa alam semesta ini berjalan sesuai dengan sunnatullah ataupun hukum-hukum Allah. Dalam matematika sendiri banyak hukum-hukum yang kia sebut dengan postulat, teorema, lemma corollary yang harus dipatuhi dan bersifat mengikat dan memaksa. Apabila tidak maka akan menyalahi aturan-aturan sehingga kesimpulan akan salah. Sehingga, dalam menjalani hidup aturan-aturan Allah harus kita laksanakan sebagai upaya simbol kepatuhan kita pada yang Maha Memberi kehidupan di alam jagad raya ini.

Disamping itu, aturan-aturan itu juga harus kita maknai sebagai upaya pendekatan diri kita kepaada Allah. Seperti contoh terdapat aturan Allah bahwa kita sebagai manusia harus berperilaku jujur, dalam konsep matematika itu sendiri prinsip kejujuran dapat kita liat pada konsep perkalian:

$+x+=+$, bermakna "jika ada suatu kebenaran dan kita katakan benar maka kita adalah golongan orang-orang yang benar"

$+x-=-$, bermakna "jika ada sebuah kebenaran dan kita mengatakannya salah maka kita merupakan golongan orang yang salah"

$-x+=-$, bermakna " jka ada sesuatu yang salah kita katakan benar kitapun menjadi orang yang salah"

${ }^{9}$ Samsul Maarif, "Integrasi Matematika Dan Islam Dalam Pembelajaran Matematika" 4, no. 2 (2015): 223-36. 
$-\mathrm{X}-=+$, bermakna “ jika ada sesuatu yang salah kita katakan salah maka insya Allah kita termasuk golongan orang-orang yang berjalan di atas kebenaran"

Artinya "yang hak harus kita katakan hak dan yang batil harus kita katakan batil". Mungkin begitu sedikit arti matematika tentang kehidupan. yang tekankan disini bahwa ternyata matematika juga mengajarkan konsep "KEJUJURAN" dalam artian yang hak harus kita katakan hak dan yang batil juga harus kita katakan batil sehingga kita termasuk golongan orang-orang yang menyeru pada kebenaran. ${ }^{10}$

c. Konsep geometri

Matematika disebut ilmu lambang dimana setiap aturan terdapat lambang atau simbol. Sebuah simbol pasti memiliki arti tersurat maupun tersirat. Sebuah simbol dalam matematika juga mungkin memiliki arti dalam kehidupan. Oleh karena itu, untuk membahas eksistensi manusia menggunakan pendekatan konsep matematika dalam hal ini geometri. Kita mulai dengan eksistensi sebuah bangun dimensi dua.
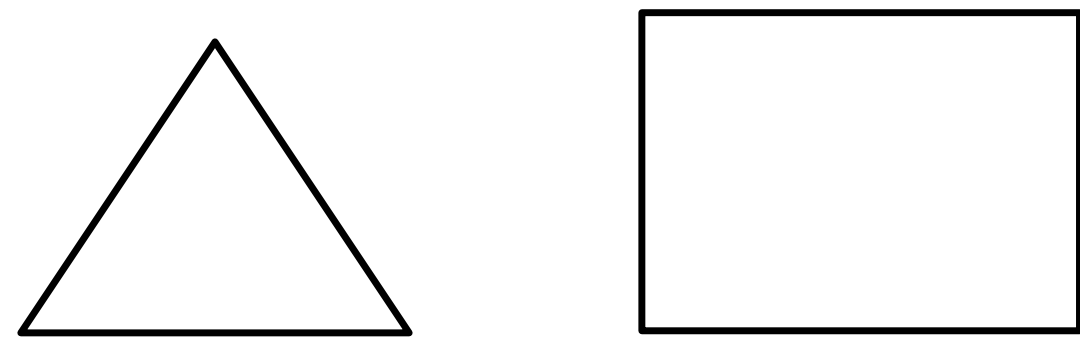

Gambar 1
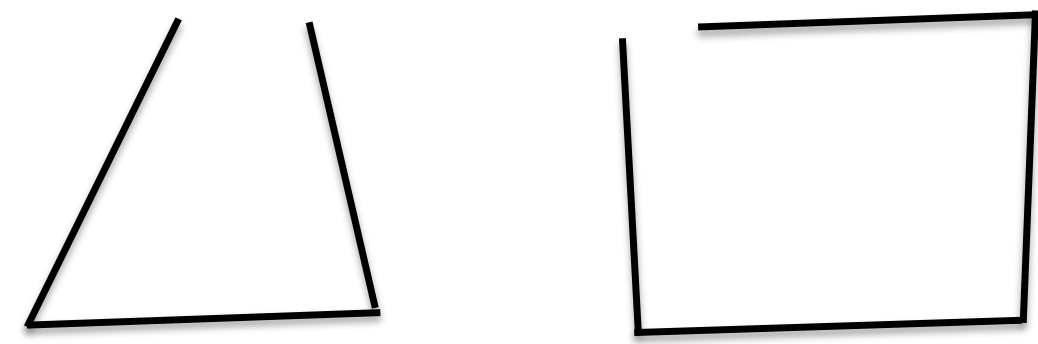

Gambar 2

Pada gambar 1 kita menyebutnya segitiga dan segiempat, tetapi pada gambar 2 meskipun memiliki tiga buah segmen garis dan empat buah segmen garis orang tidak menyebutnya segitiga ataupun segiempat. Mengapa demikian?

Dalam hal ini eksistensi segitiga dan segiempat ada karena adanya pendefinisian sehingga sebuah segitiga dan segi empat terdefinisi dengan baik (well defined). Jika boleh mendefinisasikan bahwa sebuah segitiga dibatasi oleh tiga buah sisi dan segiempat dibatasi oleh empat buah sisi yang masing-masing saling berpotongan.

\footnotetext{
${ }^{10}$ lbid.
} 
Yang membatasi keduanya adalah sisi yang berupa segmen garis. Itulah kenapa pada gambar 2 terdapat sisi yang tidak ada atau ada batasan yang hilang sehingga keduanya tidak terdefinisi dengan baik.

Analogikan suatu hal dengan salah satu sifat Allah "mukholafatullilkhawaditsi" yang artinya kurang lebih bahwa Allah itu berbeda dengan makhluk ciptaan-Nya. Setiap makhluk Allah berdimensi sehingga terbatas ataupun memiliki batasan yang kita sebut dengan sisi yang membatasi. Sedangkan Allah berbeda dengan makhluk-Nya jadi tidak terbatas ataupun tidak ada satupun yang membatasi sehingga tidak seorangpun dapat mendefinisikan Allah secara fisik.

Di samping itu, sebagai manusia yang notabenenya sebagai makhluk yang berdimensi artinya memiliki batasan-batasan sehingga dapat terdefinisi dengan baik dan bisa memiliki eksistensi dimata orang lain. Apa batasan-batasan itu? Tentunya sama yaitu dengan bangun dimensi yaitu sisi-sisi. Akan tetapi sisi-sisi tersebut berbentuk nilai-nilai agama, moral dan lain sebaganya yang menjadikan manusia bermartabat. Artinya jika seseorang melanggar batasan-batasan kehidupan sebagai manusia. Eksistensi semu yang akan didapat bagi seseorang yang mendapatkan suatu pengakuan dengan cara-cara yang keluar dari jalur dan itu bukan sifat dari sebuah makhluk yang berdimensi ataupun fitrah dari makhluk ciptaan Allah. ${ }^{11}$

\section{d. Materi himpunan}

Dalam pembelajaran matematika pada materi himpunan dapat dilakukan pembahasan tentang ayat-ayat tentang himpunan. Sebagai contoh adalah sebagai berikut:

\section{Surat Al-An'am ayat 128}

Artinya: "Dan (ingatlah) hari diwaktu Allah menghimpunkan mereka semuanya (dan Allah berfirman): "Hai golongan jin, sesungguhnya kamu telah banyak menyesatkan manusia", lalu berkatalah kawan-kawan meraka dari golongan manusia: "Ya Tuhan kami, sesungguhnya sebahagian daripada kami telah dapat kesenangan dari sebahagian (yang lain) dan kami telah sampai kepada waktu yang telah Engkau tentukan bagi kami". Allah berfirman: "Neraka itulah tempat diam kamu, sedang kamu kekal di dalamnya, kecuali kalau Allah menghendaki (yang lain)". Sesungguhnya Tuhanmu Maha Bijaksana lagi Maha Mengetahui.”

$$
\begin{aligned}
& \mathrm{S}=\text { Makhluk ciptaan Allah } \\
& \mathrm{A}=\text { Golongan Jin } \\
& \mathrm{B}=\text { Golongan Manusia }
\end{aligned}
$$

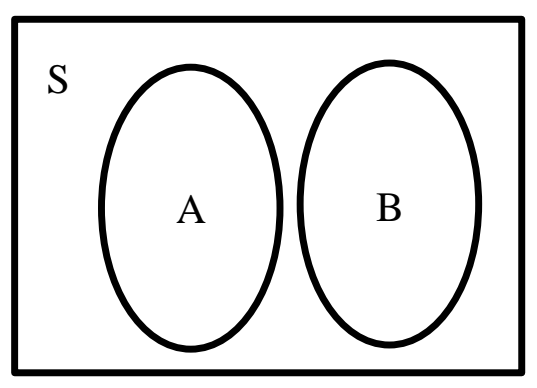

${ }^{11}$ Ibid. 


\section{Gambar 3. Diagram Venn Himpunan terlepas}

Diagram venn yang digambarkan dalam ayat diatas adalah dua himpunan yang terpisah karena tidak memiliki persamaan. Kedua himpunan tersebut masuk pada hal makhluk yang diciptakan Allah yaitu golongan jin (makhuk ghaib) dan golongan manusia.

Nilai akidah pada ayat di atas menunjukkan bahwa Allah mempunyai sifat Maha Adil, karena Allah membalas apa yang telah dilakukan manusia selama di dunia. Sekecil apapun amal perbuatan manusia akan diminta pertanggungjawabannya, baik amal baik maupun buruk. Nilai syari'ah pada ayat di atas adalah rasa tanggungjawab yang harus dimiliki oleh setiap manusia.

Bertanggungjawab sebagai hamba Allah selama hidup di dunia, dan menjadi khalifah (pemimpin, wakil) Allah selama di dunia. Perbuatan yang telah dilakukan manusia selama hidup di dunia adakalanya adalah bisikan para jin untuk melakukan perbuatanperbuatan yang dilarang Allah dan meninggalkan apa yang diperintahkan Allah. Hal ini mengisysaratkan kepada manusia untuk menjaga kedisiplinan, disiplin dalam melaksanakan hal-hal yang diperintahkan Allah, misalnya berupa ibadah-ibadah mahdlah (khusus) dan meninggalkan hal-hal yang dilarang Allah.

Nilai akhlak diatas adalah sifat 'iffah (menjaga hal-hal yang dapat menjatuhkan kehormatan diri) baik dimata Allah ataupun dimata manusia. Selain itu juga sifat amanah, dimana Allah telah mengamanahkan manusia untuk menjadi abdullah (hamba Allah).

\section{Surat Al-Waqi'ah ayat 7-10 dan ayat 14}

Yang artinya : "dan kamu menjadi tiga golongan. Yaitu golongan kanan. Alangkah mulianya golongan kanan itu. Dan golongan kiri. Alangkah sengsaranya golongan kiri itu. Dan orang-orang yang beriman paling dahulu. Mereka itulah yang didekatkan kepada Allah. Berada dalam jannah kenikmatan. Segolongan besar dari orang-orang yang terdahulu dan segolongan kecil dari orang-orang yang kemudian.”

$$
\begin{aligned}
& \mathrm{S}=\text { Manusia } \\
& \mathrm{A}=\text { Golongan Nabi dan umatnya yang beriman } \\
& \mathrm{B}=\text { Golongan kanan } \\
& \mathrm{A} \cup \mathrm{B} / \text { golongan kiri }
\end{aligned}
$$

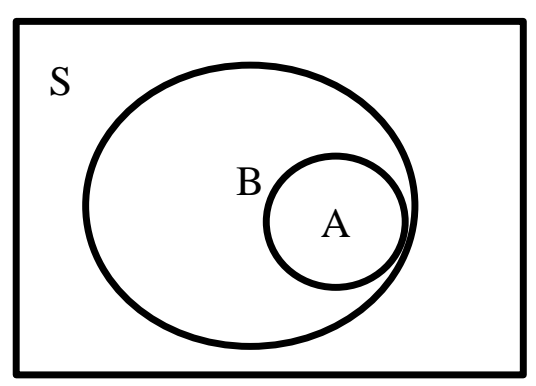

Gambar 4. A U B / golongan kiri

Diagram venn yang digambarkan diatas adalah A (Golongan Nabi dan umatnya yang beriman) merupakan subhimpunan dari B (Golongan kanan), maka perpaduan A dan B adalah B (Golongan kanan). Jadi, dalam penulisan matematika adalah A C B maka A $\cup$ B = 
B. A U B / golongan kiri (yang tidak termasuk pada golongan nabi dan umatnya yang beriman dan golongan kanan) mereka disebut sebagai golongan kiri.

Nilai akidah yang terdapat dalam ayat di atas adalah adanya Tauhid Uluhiyah. Abu Fatiah Al Adnani dikutip nihayati menjelaskan bahwa tauhid Uluhiyah merupakan inti dakwah para rasul, yaitu mengesakan Allah dengan memurnikan perbuatan para hamba semata-mata dengan niat taqarrub (mendekatkan diri) kepada Allah, seperti shalat, zakat, puasa, haji, shodaqoh, membaca AAl-Qur'an, berdzikir, tawakkal, bertaubat, dan lain-lain. Ibadah- ibadah tersebut menjadi hal-hal yang dapat menjadikan manusia menjadi golongan kanan.

Nilai syari'ah yang terkandung adalah manusia berusaha untuk menjadi golongan kanan. Golongan kanan merupakan golongan yang beruntung. Untuk menjadi golongan yang beruntung manusia hendaknya melakukan ibadah-ibadah mahdlah (ibadah khusus) secara berkelanjutan. Ibadah mahdlah contohnya adalah sholat dan puasa. Selain itu, adalah melatih manusia untuk bertanggung jawab atas semua perbuatan yang telah dilakukan. Perbuatan baik dan buruk, semua ada konsekuensi yang harus diterima oleh pelaku (manusia), dan ini berlaku baik di dunia maupun di akherat, tetapi, di akheratlah Allah seadil-adilnya hakim.

Nilai akhlak yang terkandung dalam ayat tersebut adalah untuk bersikap mujahadah. Yunahar Ilyas yang dikutip nihayati mengartikan mujahadah sebagai upaya mencurahkan segala kemampuan untuk melepaskan diri dari segala hal yang menghambat pendekatan diri terhadap Allah SWT baik dari faktor internal maupun eksternal. Setelah bermujahadah, seorang manusia hendaknya memiliki sikap istiqomah (sikap teguh dlm mempertahankan keimanan dan keislaman sekalipun menghadapi berbagai macam tantangan dan godaan).

\section{Surat Al-Fatihah ayat 7}

Artinya: “(yaitu) Jalan orang-orang yang telah Engkau beri nikmat kepada mereka; bukan (jalan) mereka yang dimurkai dan bukan (pula jalan) mereka yang sesat."

$\mathrm{A}=$ Orang-orang yang beriman kepada Allah

$\mathrm{B}=$ Orang-orang yang kafir

$\mathrm{A} \cap \mathrm{B}=$ Orang-orang munafik

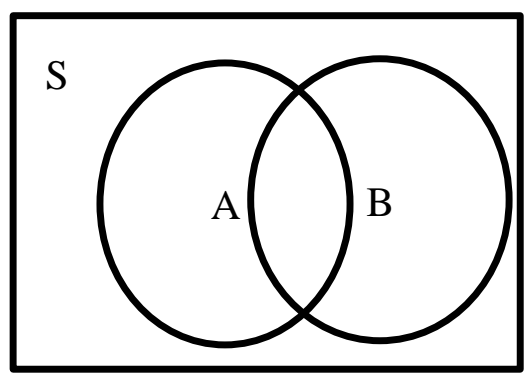

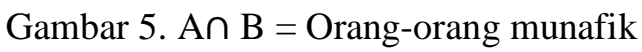

Diagram venn yang digambarkan sesuai ayat diatas adalah bentuk penggabungan himpunan A (Orang-orang yang beriman) dan himpunan B (Orang-orang kafir). $\mathrm{A} \cap \mathrm{B}=$ Orang-orang munafik yaitu orang yang beriman tetapi memiliki sifat orang-orang kafir.

Nilai akidah yang terkandung dalam ayat tersebut menunjukkan bahwa Allah Maha Pengasih dan Maha Penyayang, diantaranya adalah banyaknya nikmat yang telah diberikan 
kepada manusia. Manusia yang mampu mensyukuri apa yang sudah diberikan oleh Allah adalah orang-orang yang beriman kepada Allah. Bagi orang-orang yang tidak mau dan tidak mampu mensyukuri nikmat-nikmat Allah merupakan orang-orang kafir. Bagi manusia yang berada dalam keduanya menunjukkan bahwa orang tersebut merupakan orang munafik.

Nilai syari'ah terkandung pada ayat tersebut adalah berupaya agar menjadi hamba yang diberi nikmat oleh Allah, salah satu caranya adalah dengan melaksanakan ibadah secara disiplin. Menjaga kedisiplinan dalam beribadah mampu meningkatkan derajat manusia dihadapan Allah.

Nilai akhlak yang terkandung pada ayat di atas adalah mengisyaratkan pada manusia untuk bersikap amanah, agar tidak menjadi manusia yang memiliki salah satu sifat orang munafik, berkhianat jika diberi amanah. Selain itu, nilai akhlak yang muncul pada ayat tersebut adalah berusaha untuk tidak menjadi manusia yang dimurkai oleh Allah. Sifat yang perlu dijaga supaya tidak dimurkai oleh Allah adalah bersyukur yang merupakan lawan dari kufur, sifat tawadhu' yang lahir karena kesadaran akan ke-Maha Kuasaan Allah yang merupakan lawan dari sombong. ${ }^{12}$

e. Sistem persamaan linear

Kesatuan umat diibaratkan adanya persamaan-persamaan dalam hal membangun ummat. Dalam matematika sebuah Persamaan akan muncul ketika terdapat sebuah solusi sehingga ketika dimasukan ke dalam sebuah sistem persamaan tersebut. Sebagai contoh $3 x=9, x=3$ adalah solusi dari sebuah persamaan diatas. Bagaimana ketika terdapat dua buah persamaan yang berbeda. Maka dalam matematika dikenal dengan prinsip "Eliminasi" ataupun "Substitusi". Dalam hal ini perbedaan-perbedaan hanya dapat disatukan dengan cara mengeliminasi keegoisan pada diri kita masing-masing dan saling melengkapi kekurangan satu sama lain.

Allah berfirman dalam Surat Al Mukminun: 52-53

"Sesungguhnya agama tauhid ini adalah agama kamu semua, agama yang satu, dan AKU adalah Tuhanmu, maka bertaqwalah kepada KU, kemudian mereka (pengikutpengikut rasul itu) menjadikan agama mereka terpecah belah. Tiap-tiap golongan merasa bangga dengan apa yang ada pada diri mereka masing-masing".

Dengan mengambil hikmah dari prinsip eliminasi dan substitusi tentunya persatuan dan kesatuan umat islam akan lebih kokoh dengan meninggalakan suku, ras golongan akan tetapi tetap saling mendukung dan saling mengisi demi kejayaan ummat islam. ${ }^{13}$

\footnotetext{
${ }^{12}$ Nihayati, "Integrasi Nilai-Nilai Islam Dengan Materi Himpunan (Kajian Terhadap Ayat-Ayat AlQur'an)."

${ }^{13}$ Maarif, "Integrasi Matematika Dan Islam Dalam Pembelajaran Matematika."
} 


\section{f. Limit}

Terdapat beberapa prinsip-prinsip dalam matematika yang dapat dijadikan acuan untuk membuktikan keesaan Allah dan membuktikan sifat-sifat Allah. Seperti contoh: topik tentang konsep limit. Terdapat pertanyaan sederhana:"Dalam sebuah barisan bilangan asli yaitu $1,2,3,4, \ldots$. Barisana tersebut berhingga atau tak hingga?" kebanyakan orang menganggap "tak berhingga".

Akan tetapi, jika kita cermati lebih mendalam, bahwa pada barisan bilangan asli akan berhingga sampai $\mathrm{n}$ atau $1,2,3, \ldots, \mathrm{n}$. berapa nialai $\mathrm{n}$ nya? tergantung sampai mana kita mau akan tetapi manusia tidak mampu menjawabnya karena hanya Tuhan yang tahu. bahwa barisan tesebut akan mendekati tak hingga. Makna yang dapat kita petik dari konsep di atas, bahwa kehidupan di dunia ini tidak lain dan tidak bukan dengan kata keabadian ataupun kekekalan karena kedua sifat tersebut hanya dimiliki oleh Tuhan. Allah berfirman dalam Surat Al-Qoshoss ayat 88

"Janganlah kamu sembah di samping (menyembah) Allah, tuhan apapun yang lain. Tidak ada Tuhan (yang berhak disembah) melainkan Dia. Tiap-tiap sesuatu pasti binasa, kecuali Wajah Allah. Bagi-Nyalah segala penentuan, dan hanya kepada-Nyalah kamu dikembalikan".

Dari ayat di atas mengandung makna bahwa semua yang ada di alama ini tidaklah kekal semuanya akan binasa termasuk hukum-hukum matematika yang oleh sebagian orang dianggapnya tak terhingga. Pemikiran manusia hanya dapat mengagungkan sifat Tuhan dengan segala Ilmu yang dimilikinya. Dengan ilmu yang dimilikinya hendaknya kita dapat lebih mempertebal keimanan kita bukan malah sebaliknya kita makin jauh dari Tuhan karena merasa bahawa kita dapat menyelesaikan segala permasalahan kita dengan ilmu yang kita milki. Perlu diingat bahwa manusia adalah makhluk yang berdimensi, eksistensi setiap makhluk yang berdimensi akan terbatas. Pemikiran manusia hanya dapat mencapai sedikit dari bukti kekuasaan Allah SWT. Dan yang memiliki kekuasaan yang tak terbatas tidak lain dan tidak bukan hanya Allah SWT yang maha ESA. ${ }^{14}$

\section{SIMPULAN}

Matematika memiliki pengaruh yang besar dalam kehidupan manusia. Disadari maupun tidak, sebenarnya seseorang tidak lepas dengan matematika. Tetapi bagi sebagian besar orang menganggap bahwa matematika merupakan mata pelajaran yang amat berat dan sulit. Salah satu penyebabnya karena kajian matematika yang bersifat abstrak. Oleh karena itu, matematika perlu diperkenalkan dan diajarkan kepada siswa semenarik mungkin. Apabila matematika telah menjadi hal yang menarik untuk dipelajari, maka siswa akan merasakan bahwa matematika memang

${ }^{14}$ Ibid. 
merupakan bagian dari hidup karena keurgenan matematika tersebut. Agar matematika dapat dirasakan siswa sebagai bagian dari hidup, setiap materi matematika yang akan diajarkan harus dapat ditunjukkan aspek-aspek tertentu yang mengandung nilai-nilai dalam kehidupan. Salah satu nilai dalam kehidupan yaitu nilai islami berupa nilai akidah, nilai syari'ah dan nilai akhlak.

Ibadah dan akhlak yang harus diimplementasikan dalam kehidupan sehari-hari dalam berbagai aspek kehidupan manusia, baik dalam berhubungan dengan Tuhan, dengan sesama manusia, maupun dengan alam sekitarnya. Jika nilai-nilai ini bisa direalisasikan dalam kehidupan manusia, maka akan dihasilkan manusia yang paripurna (insan kamil) dan terciptalah kehidupan yang bermartabat.

Guna menanamkan nilai-nilai Islam melalui proses pembelajaran matematika, diperlukan strategi yang tepat. Beberapa strategi pembelajaran yang dikaitkan dengan penanaman nilai-nilai ajaran islam yang dapat dilakukan dalam pembelajaran mata pelajaran matematika, adalah selalu menyebut nama Allah, menggunakan istilah dan nama-nama islami, Ilustrasi visual, penelusuran sejarah, menyajikan materi matematika yang bermuatan nilai Islami.

\section{DAFTAR RUJUKAN}

Aji, Rizqon Halal Syah. Khasanah Sains dan Matematika dalam Islam. Jurnal Filsafat dan Budaya Hukum. Hal. 155-168.

Asyhar, Beni dan Muniri. Matematika sebagai Alternatif Media Dakwah. Prosiding SI MaNIs (Seminar Nasional Integrasi Matematika dan Nilai Islami) vol. 1, No. 1, Juli 2017, hal. 335341.

Kurniati, Annisah. Mengenalkan Matematika Terintegrasi Islam Kepada Anak Sejak Dini. Suska Journal of mathematics Education. Vol. 1, No. 1, 2015. Hal. 1-8.

Maarif, Samsul. Integrasi Matematika dan Islam dalam Pembelajaran Matematika. Jurnal Ilmiah Program Studi Matematika STKIP Siliwangi Bandung, Vol. 4, No. 2, September 2015. Hal. 223-236.

Nihayati. Integrasi Nilai-Nilai Islam dengan Materi Himpunan ( Kajian Terhadap Ayat-Ayat AlQur'an. Jurnal Edumath. Volume 3 No. 1, Januari 2017. Hal. 65-77.

Salafudin. Pembelajaran Matematika Yang Bermuatan Nilai Islam. Jurnal Penelitian Vol. 12, No. 2, November 2015. Hal. 223-243.

Tim Redaksi FOKUSMEDIA. 2006. Himpunan Peraturan Perundang-Undangan tentang Sistem Pendidikan Nasional. Bandung: FOKUSMEDIA. 